\title{
Strategy Selection of Property Business in Transit Oriented Development Area (Case Study PT. $\mathrm{XYZ})$
}

\author{
Haris Sulaksmono ${ }^{1}$,Ervina Ahyudanari ${ }^{2}$ and Buana Ma'ruf ${ }^{3}$
}

\begin{abstract}
The property business in 2018 did experience a downward trend because of the high backlog caused by oversupply. But the prospect of the property business in 2019 is quite promising and is believed to continue to prosper. The research base is a case study at PT XYZ, one of the subsidiaries of BUMN Construction Services which is engaged in the development of the property of the Transit Oriented Development (TOD) area of the Light Rail Transit (LRT) in Jakarta. This study aims to obtain a superior strategy in the competition of the property business in the TOD region which makes added value for PT XYZ so that it can compete with other developers. The company's strategy for PT XYZ was formulated using David's strategy formulation framework, which consisted of input stages, matching stages and decision stages. The Analytical Hierarchy Process (AHP) is used to determine the weight of internal and external strategic factors and Quantitative Strategic Planning Matrix (QSPM) to determine alternative chosen strategies. Based on the results of the QSPM assessment of PT XYZ, founded the construction and pre cast concrete division strategy gets a Total Attractive Score (TAS) of 5.60, higher than $P T X Y Z$ cooperates with top property marketing companies for 3 years strategy that gets a score of 4.12.
\end{abstract}

Keywords-Analytical Hierarchy Process, Strategic Management, Property, Transit Oriented Development.

\section{INTRODUCTION ${ }^{1}$}

The policy of building one million houses per year by the government for the community, which includes houses for Low-Income Communities (MBR) and non-MBR homes, has also become a driving factor in the property business in recent years. and monetary, which increases people's purchasing power towards property. Based on the 2017 PWC study, the estimated property market is still a large train at $535.1 \mathrm{~T}$ in 2016, and is expected to grow rapidly with a CAGR of $11 \%$ (2016-2019).

\footnotetext{
${ }^{1}$ Haris Sulaksmono is with Department of Bussines and Management Technology, Institut Teknologi Sepuluh Nopember, Indonesia. Email: sulaksmono@gmail.com.

${ }^{2}$ Ervina Ahyudanari is with Departement of Civil Engineering, Institut Teknologi Sepuluh Nopember, Indonesia. Email: ervina.ariatedja@gmail.com.

${ }^{3}$ Buana Ma'ruf is with Center of Maritime Industry Technology and Engineering, Badan Pengkajian dan Penerapan Teknologi. Email: buana.maruf@bppt.co.id.
}

Jakarta is growing very rapidly, more than 18.6 million private vehicles in Jakarta while the users of public transport in the Capital City have only reached 24 percent and around 47.5 million people move in Jabodetabek. BPS DKI Jakarta in 2015 noted that every day there are around 1.4 million commuters from the area around the Capital City. The rapid and under-controlled trend of expansion in the Jakarta-Bodetabek area significantly increases transportation costs, reduces the level of mobility, and decreases the quality of life. Building the city of Jakarta extensively horizontally by relying solely on road networks and private vehicles will result in larger, inefficient, wasteful and uncontrolled developing cities. This issue prompted the government to develop the concept of transit oriented development (TOD) in several stations. TOD is an urban area designed to integrate the functions of transit with humans, activities, buildings, and public spaces that aim to optimize access to public transportation so that it can support passenger carrying capacity.

Appointment of PT. A becomes a Design and Build Light Rail Transit (LRT) contractor as an effort to improve transportation problems in Jakarta has created a business opportunity that can generate potential income. Provision of supporting facilities for LRT stations has now developed into integrated development areas, residential areas, offices and commercial areas. All of these are opportunities that can be developed to increase corporate value. This study reviews the competitive internal and external environmental factors of the property business competition in the TOD area that is integrated with LRT and MRT in Jakarta. From internal and external factors that have been given a rating and weight through AHP, it is used to formulate a competitive strategy with the framework of David's strategy formulation, which consists of input stages, matching stages and decision stages so that the best strategy is obtained for PT XYZ to excel in the property business competition in Jakarta.

\section{METHOD}

\section{A. Transit Oriented Development Concept}

According to Taolin (2008) Transit-based regional development movement is based on the deteriorating quality of city life which is characterized by congestion, sprawl, and non-integrated land use. TOD has the goal of 
creating goals that are comfortable, safe, enjoyable and sufficient for walkable environments. The TOD concept is intended as a solution for urban development through development oriented to the transit system so that it has the potential to reduce household transportation costs and improve quality of life. On the other hand, the development of mixed-use areas is expected to increase regional accessibility and reduce travel needs which ultimately reduce environmental impacts and provide alternative solutions to avoid traffic congestion. (Ditmarr and Ohland; 2004). Currently the TOD project in Jakarta is managed by state-owned companies. Such as Perum Perumnas which works on TOD Tanjung Tanjung Station, TOD Pondok China Station and TOD Bogor Station, or PT PP Properti (Persero) TBk which works on Juanda TOD Station and Tanah Abang Station TOD and PT XYZ which works on a number of TOD projects titled LRT City in several stations and Private Developers (Table 1).

TABEL 1.

DEVELOPER LIST OF JAKARTA TOD

\begin{tabular}{|c|c|c|c|}
\hline COMPANY & PROJECTLOCATION & PRODUCT & $\begin{array}{l}\text { TRASPORT } \\
\text { IWTEGRATION }\end{array}$ \\
\hline PTXYZ & $\begin{array}{l}\text { St. Bekasi Timur } \\
\text { St. Sentul } \\
\text { St. Jati Cempaka } \\
\text { St. Ciracas }\end{array}$ & $\begin{array}{l}\text { Mall Apartment } \\
\text { Commercial } \\
\text { Office } \\
\text { Hotel and Condotel }\end{array}$ & LRT \\
\hline $\begin{array}{l}\text { PT.PP Properti- PT. } \\
\text { KAI }\end{array}$ & St. Juanda & $\begin{array}{l}\text { Owned Flats } \\
\text { Owned Simple Apartment }\end{array}$ & MRT \\
\hline $\begin{array}{l}\text { Perum Perumnas. } \\
\text { PT. KAI }\end{array}$ & $\begin{array}{l}\text { St. Tanjung Barat } \\
\text { St.PondokCina }\end{array}$ & $\begin{array}{l}\text { Owned Flats } \\
\text { Owned Simple Apartment }\end{array}$ & MRT \\
\hline PT.MRT & $\begin{array}{l}\text { St. Lebak Bulus } \\
\text { St. Dukuh Atas }\end{array}$ & $\begin{array}{l}\text { Owned Flats } \\
\text { Owned Simple Apartment } \\
\text { Office and Commercial }\end{array}$ & MRT \\
\hline PT. Wika Gedung & St.Pasar Senen & $\begin{array}{l}\text { Owned Flats } \\
\text { Owned Simple Apartment }\end{array}$ & MRT \\
\hline Pikko Group & $\begin{array}{l}\text { St. Cawang } \\
\text { St. Cikooko }\end{array}$ & $\begin{array}{l}\text { Apartment } \\
\text { Retail \& Mini office } \\
\text { Lifestyle Center }\end{array}$ & LRT \\
\hline $\begin{array}{l}\text { PT.Agung } \\
\text { Podomoroland }\end{array}$ & St. Cimangegis & $\begin{array}{l}\text { Mall Apartment } \\
\text { Commercial } \\
\text { Office }\end{array}$ & LRT \\
\hline
\end{tabular}

B. Management Strategic Concept

Strategic Management can be defined as art and knowledge in formulating, implementing, and evaluating cross-functional decisions so that an organization is able to achieve its objectives [1]. Many existing strategic management models are developed for general industry, and most of them are limited to a conceptual model without formulation framework. Among them, David's model is the only quantitative and application-oriented model that emphasizes formulation into a methodological procedural framework. David's model integrates nine formulation methods into three stages: input stage, matching stage, and decision stage [1]. In the input stage, three matrices are applied, including the internal factor evaluation (IFE) matrix, the external factor (EFE), and the competitive profile matrix (CPM). At the matching stage, there are five formulation methods, or matrices, used, including the strength-weakness-opportunity-threat (SWOT) matrix, the internal external (IE) matrix, the Boston Consultative Group (BCG) matrix, the strategic position and action evaluation (SPACE) matrix and the grand strategy (GS) matrix. Selected strategies form this stage are then evaluated at the decision stage, using the quantitative strategic planning (QSPM) matrix.

Alternative strategies can be categorized into 11 strategies [1]: forward integration, backward integration, horizontal integration, market penetration, market development, product development, related diversification, unrelated diversification, retrenchment, divestiture and liquidation as shown at Tabel 2.

TABEL 2.

ALTERNATIVE StRATEgIES AND EXAMPLES OF THEIR APPLICATION [1].

\begin{tabular}{|c|c|c|}
\hline Strategy & Definition & Example \\
\hline Forward Integration & $\begin{array}{l}\text { Gaining ownership or increaved control over distributors } \\
\text { of retallers }\end{array}$ & $\begin{array}{l}\text { Amazon began rapid delivery services in some } \\
\text { U.S. cities. }\end{array}$ \\
\hline Backward Integration & $\begin{array}{l}\text { Secking ownerstip ar increased control of a firm's } \\
\text { suppliers }\end{array}$ & Starbucks purchised a coffice farm. \\
\hline Horizontal Integration & Seeking ownership or increased control over competitors & BB\&T acquired Susquehanna Bancshares. \\
\hline Market Penetration & $\begin{array}{l}\text { Seeking increased market share for present products or } \\
\text { servies in present markets through greater marketing } \\
\text { efforts }\end{array}$ & $\begin{array}{l}\text { Under Armour signed tennis champion Andy } \\
\text { Murray to a 4-year, } \$ 23 \text { million marketing deal. }\end{array}$ \\
\hline Market Development & $\begin{array}{l}\text { Introducing present products or services into new } \\
\text { geographic area }\end{array}$ & Gap opened its first five stores in China. \\
\hline Product Development & $\begin{array}{l}\text { Seeking increased sales by improwing present products or } \\
\text { services or developing new ones }\end{array}$ & $\begin{array}{l}\text { Amazon just began offering its own line of baby } \\
\text { diapers and wipes. }\end{array}$ \\
\hline Related Diversification & Adding new but related products or services & $\begin{array}{l}\text { Facebook acquired the text-messaging firm } \\
\text { WhatsApp for S19 billion. }\end{array}$ \\
\hline Unrelated Diversification & Adding new, unrelated products or services. & $\begin{array}{l}\text { Kroger and Whole Foods Market are cooking } \\
\text { meals, becoming restaurants. }\end{array}$ \\
\hline Retrenchment & $\begin{array}{l}\text { Regrouping through cost and asset reduction to reverse } \\
\text { declining sales and profit }\end{array}$ & $\begin{array}{l}\text { Staples closed } 250 \text { stores and reduced by } 50 \% \\
\text { the size of other store. }\end{array}$ \\
\hline Divestiure & Selling a division or part of an organization & $\begin{array}{l}\text { Sears Holdings divested its Land's End division } \\
\text { to Sean' sharekolders. }\end{array}$ \\
\hline Liquidation & $\begin{array}{l}\text { Selling all of a company's assets, in parts, for their } \\
\text { tangible worth }\end{array}$ & $\begin{array}{l}\text { The Trump Taj Mahal in Attantic City, New } \\
\text { Jensey, faces hiquidation. }\end{array}$ \\
\hline
\end{tabular}

\section{RESEARCH METHODOLY}

As shown in Fig. 1, the framework of this research was initiated by David's strategic framework. From literature review, Focus Group Discussion (FGD), and questionnaires to board of director and top management of PT XYZ, all relevant variables (internal and external factors) for sustainable competitive advantages were identified. The population of this study is top management of PT XYZ. Sampling in this study using purposive sampling because researchers have a goal to get subjects who have certain characteristics, or get comparable research groups so that they can be analyzed validly.

According to Zikmund in Kuncoro the use of a type of sample judgment is done to fulfill the purpose that the population has certain characteristics. Data processing is done by using Analytical Hierarchy Process (AHP) to determine the weight and internal and external strategic factor variables of the property business to then analyze the strategy formulation. The modified David Framework integrates seven formulation methods into three stages: input stage, matching stage, and decision stage [1], at the input stage, three matrices are applied, including internal factor evaluation matrix (IFE), external factor evaluation matrix (EFE), and competitive profile matrix (CPM) 


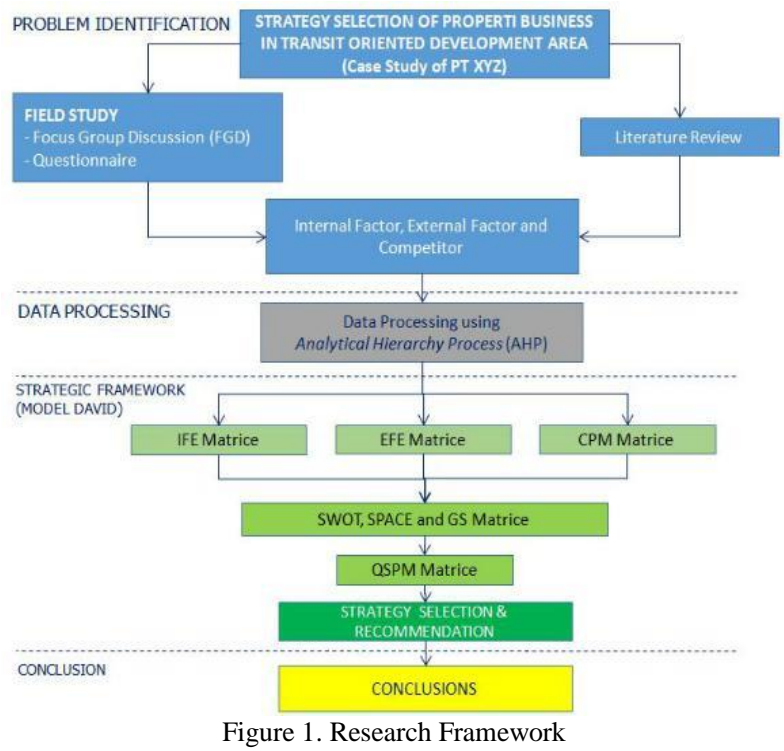

At the matching stage, there are three formulation methods, or matrices, that are used, including the strengthweakness-opportunity-threat (SWOT) matrix, strategic position and action evaluation (SPACE) matrix, and grand strategy matrix (GS). The strategies chosen from this stage are then evaluated at the decision stage, using the quantitative strategic planning matrix (QSPM).

\section{ANALYSIS AND RESULT}

All factors and variables resulting from the analytical hierarchy process are used to develop the business environment model of property at Transit Oriented Development area. Since the total weighting of variables is equal to 1.00 , the individual weighting is the given based on percentage of variance of the factors and the factor loading of the variables. Based on the results of strategy formulation assisted by three tools (SWOT Matrix, SPACE Matrix and Grand Strategy Matrix), an alternative strategy comparison can be used by PT XYZ according to Table 3 .

From the results of the comparison of alternative strategies in Table 3, it can be seen that there are two alternative strategies that are most formulated by the three tools, the alternative strategies are: Backward integration strategy, this strategy applied with PT XYZ founded the construction and pre-cast concrete division with the intention to obtain ownership or increase control of supplier companies and market penetration strategy applied with PT XYZ cooperates with top property marketing companies for 3 years to increase market share in the same market with more intensive marketing efforts. From the two most formulated alternative strategies above, it is necessary to determine which strategy is most suitable for the current state of the company.

TABLE 3.

ALTERNATIVE STRATEGIES FOR PT XYZ

\begin{tabular}{|l|c|c|c|c|}
\hline ALTERNATIVESTRATEGY & SWOTMATRICE & SPACE MATRICE & $\begin{array}{c}\text { GRAND STRATEGY } \\
\text { MATRICE }\end{array}$ & TOTAL \\
\hline Forward Integration & & $\mathrm{v}$ & $\mathrm{v}$ & 2 \\
\hline Backward Integration & $\mathrm{v}$ & $\mathrm{v}$ & $\mathrm{v}$ & 3 \\
\hline Horizontal Integration & & $\mathrm{v}$ & $\mathrm{v}$ & 2 \\
\hline Market Penetration & $\mathrm{v}$ & $\mathrm{v}$ & $\mathrm{v}$ & 3 \\
\hline Market Development & & $\mathrm{v}$ & $\mathrm{v}$ & 2 \\
\hline Product Development & & $\mathrm{v}$ & $\mathrm{v}$ & 2 \\
\hline Related Diversification & & $\mathrm{v}$ & $\mathrm{v}$ & 2 \\
\hline Unrelated Diversification & & $\mathrm{v}$ & & 1 \\
\hline Retrenchment & & & & \\
\hline Divestiture & & & & \\
\hline Liquidation & & & & \\
\hline
\end{tabular}

Therefore, each of the two strategies above is assessed using the Quantitative Strategic Planning Matrix (QSPM) method. This method is a method for selecting which strategy is most suitable by choosing the highest Total Attractive Score (TAS). Table 4 is the result of the QSPM matrix assessment between the backward integration strategy and market penetration strategy, this assessment was carried out through discussions with one of the managers of PT XYZ.

Based on the results of the QSPM assessment in Table 4, it can be seen that the alternative strategy that is in accordance with the conditions of the company PT XYZ at present is backward integration with in founded the construction and pre cast concrete division strategy. This alternative PT XYZ founded the construction and pre cast concrete division strategy gets a Total Attractive Score (TAS) of 5.60, higher than PT XYZ cooperates with top property marketing companies for 3 years strategy that gets a score of 4.12

TABLE 4.

QSPM MATRIX ASSESSMENT OF PT. XYZ

\begin{tabular}{clccccc}
\hline \hline & & \multicolumn{3}{c}{$\begin{array}{c}\text { Founded the construction and } \\
\text { pre-cast concrete division }\end{array}$} & $\begin{array}{c}\text { Cooperates with top property } \\
\text { marketing companies for 3 years }\end{array}$ \\
\hline No & Strengths & Weight & AS & TAS & AS & TAS \\
1 & Property Location & 0.22 & 4 & 0.88 & 4 & 0.88 \\
2 & Property Price Level & 0.19 & 3 & 0.57 & 4 & 0.76 \\
3 & Property Facilities & 0.14 & 0 & 0 & 2 & 0.28 \\
4 & Design Engineering & 0.05 & 2 & 0.1 & 3 & 0.16
\end{tabular}


The $1^{\text {st }}$ International Conference on Business and Management of Technology (IConBMT)

August 3rd 2019, Institut Teknologi Sepuluh Nopember, Surabaya, Indonesia

\begin{tabular}{|c|c|c|c|c|c|c|}
\hline 5 & Property Quality Insurance & 0.04 & 4 & 0.17 & 1 & 0.04 \\
\hline 6 & Business Network & 0.02 & 2 & 0.04 & 4 & 0.08 \\
\hline 7 & Top Management Competencies & 0.02 & 1 & 0.02 & 3 & 0.06 \\
\hline \multirow[t]{2}{*}{8} & Construction Company & 0.02 & 2 & 0.03 & 0 & 0 \\
\hline & Weaknesses & Weight & AS & TAS & AS & TAS \\
\hline 1 & Delivery Time & 0.09 & 3 & 0.26 & 2 & 0.17 \\
\hline 2 & Capital and Financial of Company & 0.07 & 3 & 0.22 & 2 & 0.15 \\
\hline 3 & Business Development and Market Research & 0.05 & 3 & 0.15 & 3 & 0.15 \\
\hline 4 & Contract and Legal Aspect & 0.03 & 0 & 0 & 3 & 0.09 \\
\hline 5 & Special Resources & 0.02 & 1 & 0.02 & 3 & 0.06 \\
\hline 6 & Structure Organization of Company & 0.02 & 0 & 0 & 2 & 0.03 \\
\hline 7 & Industrial Relation & 0.02 & 3 & 0.05 & 3 & 0.05 \\
\hline \multirow[t]{2}{*}{8} & Employee Know-How & 0.01 & 2 & 0.02 & 3 & 0.04 \\
\hline & Opportunities & Weight & AS & TAS & AS & TAS \\
\hline 1 & Material Quality & 0.15 & 3 & 0.45 & 1 & 0.15 \\
\hline 2 & Brand Image & 0.13 & 3 & 0.38 & 4 & 0.51 \\
\hline 3 & Bank Support & 0.1 & 2 & 0.19 & 2 & 0.19 \\
\hline 4 & Domestic Market & 0.07 & 1 & 0.07 & 3 & 0.2 \\
\hline 5 & Government Support & 0.03 & 0 & 0 & 2 & 0.06 \\
\hline 6 & Contractor and Supllier Know-how & 0.03 & 3 & 0.08 & 1 & 0.03 \\
\hline 7 & Availibility of Main Contractor and Supplier & 0.02 & 3 & 0.06 & 0 & 0 \\
\hline \multirow[t]{2}{*}{8} & Employee Training Program & 0.02 & 2 & 0.04 & 3 & 0.05 \\
\hline & Threats & Weight & AS & TAS & AS & TAS \\
\hline 1 & Purchasing Power of Buyer & 0.11 & 2 & 0.23 & 3 & 0.34 \\
\hline 2 & Price of Material & 0.09 & 3 & 0.28 & 2 & 0.19 \\
\hline 3 & Competition Climate of Property Developer & 0.06 & 4 & 0.24 & 3 & 0.18 \\
\hline 4 & Wage Level of Construction Work/Company & 0.06 & 3 & 0.17 & 2 & 0.12 \\
\hline 5 & $\begin{array}{l}\text { Social and cultural conditions of the development } \\
\text { area }\end{array}$ & 0.04 & 2 & 0.09 & 2 & 0.09 \\
\hline 6 & Security andPolitical Stability & 0.04 & 4 & 0.15 & 1 & 0.04 \\
\hline 7 & Local Barrier & 0.03 & 1 & 0.03 & 1 & 0.03 \\
\hline 8 & Availibility of Supporting Industries & 0.03 & 3 & 0.08 & 0 & 0 \\
\hline
\end{tabular}

\section{CONCLUSION}

David's models for strategy formulation could be used to develop and to formulate the corporate strategy of PT XYZ. Based on the results of QSP matrix, the selected strategy founded the construction and pre cast concrete division (TAS 5.60) and cooperate with top property marketing companies strategy (TAS 4.12) as the second alternative strategies. The identification of strategic internal and external factors in the David's model could be enhanced further by applying other statistical method like Factor Analysis. For company, David's model of strategy formulation could become one alternative in formulating corporate strategy in the property industry despite its limited application in the field while for academia, more research on the application of David's model in the property company should be promoted to see how effective the model works in the industry.

\section{REFERENCES}

[1] F. R. David and F. R. David, Strategic Management: Concepts and Cases: A Competitive Advantage Approach. Essex, UK: Pearson Education, 2017. 